\title{
HUBUNGAN TINGKAT PENGETAHUAN IBU TENTANG IMUNISASI DENGAN KELENGKAPAN IMUNISASI DASAR ANAK DI BPM BIDAN SUTARTI, AMD., KEB KOTA MADIUN
}

\author{
Relationship Of Mom's Knowledge Level About Immunization \\ With Complete Children's Basic Immunization \\ In Bpm Bidan Sutarti, Amd., Keb \\ Madiun City
}

\author{
Nisa Ardhianingtyas \\ Akademe Kebidanan Muhammadiyah Madiun \\ nisaardy182@gmail.com
}

\begin{abstract}
ABSTRAK
Latar belakang; Imunisasi merupakan usaha memberikan kekebalan pada bayi dan anak untuk mencegah terhadap penyakit tertentu. Berdasarkan studi pendahuluan di BPM Ny. Sutarti, Amd., Keb dari 10 ibu yang mengimunisasi dasar bayinya, di dapatkan $(60 \%)$ ibu tepat mengimunisasikan bayinya dan (40\%) tidak tepat mengimunisasikan bayinya. Pengetahuan ibu tentang imunisasi akan mempengaruhi pelaksanaan imunisasi. Apabila pengetahuan ibu tentang pemberian imunisasi baik diharapkan pemberian imunisasi pada anak sesuai jadwal. Tujuan Penelitian; Untuk mengetahui hubungan tingkat pengetahuan ibu tentang imunisasi dengan kelengkapan imunisasi dasar anak. Metode Penelitian; observasional analitik dengan pendekatan waktu Cross Sectional terhadap ibu-ibu yang mengimunisasikan lengkap dasar anaknya yaitu sejumlah 22 orang selama 2 bulan. Untuk mengetahui hubungan tingkat pengetahuan ibu tentang imunisasi dengan kelengkapan imunisasi dasar anak digunakan rumus chi square. Hasil Penelitian; Diperoleh 14 responden (63.6\%) berpengetahuan tinggi, 5 responden (22.7\%) berpengetahuan sedang dan 3 responden berpengetahuan rendah (13.6\%), sedangkan responden memberikan imunisasi secara lengkap sebanyak 19 responden (86.4\%) dan yang tidak memberikan imunisasi secara lengkap sebanyak 3 responden (13.6\%). Analisa data menggunakan chi s-quare dengan $\mathrm{p}$ value $=0.410$, diperoleh hasil $\mathrm{X}_{\text {hitung }}<\mathrm{X}_{\text {tabel }}$ sehingga Ho diterima. Kesimpulan; Penelitian menunjukkan bahwa tidak ada hubungan antara tingkat pengetahuan ibu tentang imunisasi dengan kelengkapan imunisasi dasar anak.
\end{abstract}

Kata Kunci : Pengetahuan, Imunisasi, Imunisasi Dasar Anak

\begin{abstract}
Background; Immunization is an effort to provide immunity to infants and children to prevent certain diseases. Based on a preliminary study at BPM Ny. Sutarti, Amd., Keb of 10 mothers who immunized their babies base, in getting $(60 \%)$ mothers properly immunized their babies and $(40 \%)$ did not properly immunize their babies. Knowledge of mothers about immunization will affect the implementation of immunization. If the mother's knowledge about giving good immunization is expected to provide immunization to children on schedule. Research purposes; To find out the relationship between the level of knowledge of mothers about immunization and the completeness of basic childhood immunizations. Research methods; Observational analytics with a Cross Sectional time approach to mothers who fully immunize their children, namely 22 people for 2 months. To find out the relationship between the level of knowledge of mothers about immunization and the completeness of basic immunizations of children used the chi square formula. Research result; 14 respondents $(63.6 \%)$ had high knowledge, 5 respondents $(22.7 \%)$ were moderate knowledge and 3 respondents were knowledgeable low (13.6\%), while respondents gave complete immunizations of 19 respondents $(86.4 \%)$ and those who did not give a complete immunization of 3 respondent (13.6\%). Data analysis using s-quare chi with $\mathrm{p}$ value $=0.410$, obtained results of Xcount $<$ Xtabel so that Ho is accepted. Conclusion; Research shows that there is no relationship between the level of knowledge of mothers about immunization and the completeness of basic childhood immunizations.
\end{abstract}

Keywords : Knowledge, Immunization, Basic Child Immunization 


\section{PENDAHULUAN}

Imunisasi merupakan usaha memberikan kekebalan pada bayi dan anak dengan memasukkan vaksin ke dalam tubuh agar tubuh membuat zat anti untuk mencegah terhadap penyakit tertentu (Hidayat, 2007). Walaupun pada saat ini fasilitas pelayanan untuk vaksinasi ini telah tersedia di masyarakat, tetapi tidak semua bayi telah dibawa untuk mendapatkan imunisasi lengkap. Imunisasi seharusnya diketahui oleh setiap keluarga dan masyarakat. Tanpa imunisasi, kira-kira 3 dari 100 kelahiran anak akan meninggal karena batuk rejan. 1 dari 100 kelahiran anak akan meninggal karena penyakit tetanus, dan dari setiap 200.000 anak, 1 akan menderita penyakit polio (Anonim, 2007).

Tiap bayi lahir sebenarnya telah dibekali oleh alam dengan kekebalan terhadap pelbagai jenis infeksi. Kekebalan tersebut diperoleh dari ibunya, yang memberikan zat anti darah ibu ke darah bayi melalui plasenta. Kekebalan pasif ini biasanya bersifat kurang kuat, akan berangsur-angsur berkurang dan kemudian menghilang dalam waktu beberapa minggu sampai beberapa bulan setelah bayi lahir (Sastroasmoro, 2007: 126). Dewasa ini telah diketahui cara imunisasi untuk banyak penyakit infeksi. Sebagian besar penyakit tidak dapat dicegah dengan imunisasi, karena sebagian besar penyakit tidak dapat merangsang timbulnya zat anti yang berlangsung lama (Sastroasmoro, 2007).

Target UCI (Universal Child Immunization) 80-80-80 merupakan tujuan antara (intermediate goal), yang berarti cakupan imunisasi untuk BCG, DPT, polio, campak, dan hepatitis B harus mencapai $80 \%$ baik di tingkat nasional, propinsi, dan kabupaten bahkan di setiap desa. Seluruh propinsi (97\% dari 302 kabupaten) di Indonesia telah mencapai target UCI. Data Subdit Imunisasi Ditjen PPM\&PLP DepKes 2004, cakupan imunisasi di Indonesia tahun 2003 untuk 1 dosis BCG 97,7\%, 3 dosis DPT $90,8 \%, 3$ dosis Hep. B 79,4 \%, 1 dosis campak $90 \%$ (Ranuh, 2008).

Pengetahuan ibu tentang imunisasi mempengaruhi pelaksanaan imunisasi. Bila pengetahuan ibu tentang imunisasi kurang, tidak merasa butuh atau sekedar ikut-ikutan maka pemberian imunisasi pada anaknya tidak sesuai dengan jadwal, baik waktu maupun jaraknya. Apabila pengetahuan ibu tentang pemberian imunisasi baik diharapkan pemberian imunisasi sesuai jadwal, sehingga program imunisasi memenuhi kuantitas dan kualitas kesehatan bayi, akhirnya berdampak pada peningkatan status kesehatan dan sumber daya masyarakat di masa depan (Avid, 2008).

Berdasarkan studi pendahuluan di BPM Bidan Sutarti Kota Madiun tanggal 11 Januari 2017 dari 10 ibu yang mengimunisasi dasar bayinya di dapatkan $(60 \%)$ ibu tepat mengimunisasikan bayinya dan $(40 \%)$ tidak tepat.

Dari data tersebut di atas maka penulis tertarik mengambil judul "Hubungan Tingkat Pengetahuan Ibu tentang Imunisasi dengan Kelengkapan Imunisasi Dasar Anak di BPM Bidan Sutarti, Amd., Keb., Kota Madiun”.

\section{METODE}

Penelitian dilakukan di BPM Bidan Sutarti, Amd., Keb., Kota Madiun dan dilaksanakan pada tanggal 16 Pebruari 2017. Penelitian ini menggunakan metode non eksperimen dengan desain observasional analitik. Peneliti mencoba untuk mencari hubungan antara variabel faktor resiko dan efek yang analisisnya untuk menentukan ada tidaknya hubungan antar variabel itu, sehingga perlu disusun hipotesisnya dengan menggunakan pendekatan cross sectional yaitu jenis penelitian yang menekankan pada waktu pengukuran atau observasi data variabel independen dan dependen hanya satu kali, pada satu saat (Sugiyono, 2007). Populasi yang digunakan dalam penelitian ini adalah ibu-ibu yang mengimunisasikan dasar anaknya selama 2 bulan di BPM Bidan Sutarti, Amd., Keb yaitu sejumlah 22 orang. Pengambilan sampel dilakukan dengan teknik total sampling. Variabel bebas dalam penelitian ini adalah tingkat pengetahuan ibu tentang imunisasi, sedangkan variabel terikat adalah kelengkapan imunisasi dasar anak. Variabel menggunakan skala data ordinal. Alat ukur yang digunakan adalah kuisioner.

Validitas adalah sejauh mana pengukuran yang dilakukan benar-benar mengukur apa yang seharusnya diukur. Reliabilitas adalah sejauh mana instrumen menghasilkan pengukuran yang sama meskipun digunakan oleh pengamat yang berbeda pada waktu yang sama (Azwar, 2008).Uji validitas untuk mengukur variabel bebas menggunakan alat bantu komputer program SPSS (Statistical Product and Service 
Solution) versi 15 Windows XP. Adapun untuk pengujian tes digunakan teknik korelasi Point Biserial. Uji Reliabilitas menggunakan Kruder Richardson-20 atau KR-20.

Analisis data dilakukan dengan menggunakan SPSS (Software Statistical Program Social Science). Analisis bivariat yang dilakukan terhadap dua variabel, yaitu variabel bebas pengetahuan ibu tentang imunisasi dan variabel terikat kelengkapan imunisasi dasar anak yang diduga berhubungan atau berkorelasi (Notoatmodjo, 2007). Analisis dalam penelitian ini menggunakan uji statistik non parameter teknik analisis bivariat dengan uji chi square.

\section{HASIL DAN PEMBAHASAN HASIL}

Tabel Distribusi Tingkat Pengetahuan

\begin{tabular}{ccc}
\hline Kategori & Frekuensi & Persentase \\
\hline Tinggi & 14 & 63,6 \\
Sedang & 5 & 22,7 \\
Rendah & 3 & 13,6 \\
\hline Total & 22 & 100 \\
\hline
\end{tabular}

Tabel Distribusi Frekunsi Kelengkapan Imunisasi Dasar

\begin{tabular}{ccc}
\hline Kategori & Frekuensi & Persentase \\
\hline Lengkap & 19 & 86,4 \\
Tidak & 3 & 13,6 \\
Lengkap & & \\
\hline Total & 22 & 100 \\
\hline
\end{tabular}

Dari Cross Tabulation Tingkat Pengetahuan dan Kelengkapan Imunisasi Dasar dapat diketahui bahwa responden dengan tingkat pengetahuan tinggi mengimunisasikan lengkap sebanyak 12 responden $(54.5 \%)$, dan mengimunisasikan secara tidak lengkap sebanyak 2 responden (9.1\%), dari total responden dengan tingkat pengetahuan tinggi 14 responden (63.6\%).

Responden dengan tingkat pengetahuan sedang mengimunisasikan lengkap sebanyak 5 responden $(22.7 \%)$, dan mengimunisasikan secara tidak lengkap sebanyak 0 responden $(.0 \%)$ dari total responden dengan tingkat pengetahuan sedang 5 anak $(22.7 \%)$.

$$
\begin{aligned}
& \text { Responden dengan tingkat } \\
& \text { pengetahuan rendah mengimunisasikan } \\
& \text { lengkap sebanyak } 2 \text { responden }(9.1 \%) \text {, dan } \\
& \text { mengimunisasikan secara tidak lengkap } \\
& \text { sebanyak } 1 \text { responden }(4.5 \%) \text { dari total }
\end{aligned}
$$

responden dengan tingkat pengetahuan rendah 3 responden $(13.6 \%)$.

Hasil penelitian dasar uji chi square yang dilakukan dengan program SPSS for windows menunjukkan pValue: $0.410>0.05$ dan $\mathrm{X}^{2}$ hitung $1.783<\mathrm{X}^{2}$ tabel $(1.783<5.991)$ maka Ho diterima dan Ha ditolak.

\section{PEMBAHASAN}

Dari hasil penelitian responden berdasarkan tingkat pengetahuan jumlah responden mayoritas yang mempunyai tingkat pengetahuan tinggi sebanyak 14 responden (63.6\%), sedangkan responden dengan pengetahuan rendah sebanyak 3 responden $(13.6 \%)$.

Dari hasil penelitian responden berdasarkan kelengkapan imunisasi dasar diatas diperoleh hasil terbanyak yaitu 19 responden (86.4\%) yang mengimunisasikan lengkap anaknya, sedangkan ibu yang tidak mengimunisasikan bayinya lengkap yaitu sebanyak 3 responden (13.6\%).

Setelah diketahui hasil dari cross tabulations antara tingkat pengetahuan ibu tentang imunisasi dengan kelengkapan imunisasi dasar anak kemudian data dianalisa untuk mencari hubungan kedua variabel dengan rumus chi square. Hasil penelitian dasar uji chi square yang dilakukan dengan program SPSS for windows menunjukkan pValue: $0.410>0.05$ dan $\mathrm{X}^{2}$ hitung $1.783<$ $X^{2}$ tabel $(1.783<5.991)$ maka Ho diterima dan Ha ditolak, disimpulkan tidak ada hubungan antara tingkat pengetahuan ibu dengan kelengkapan imunisasi dasar anak.

Tercapainya kelengkapan imunisasi tidak lepas dari peran aktif tenaga kesehatan dalam memberikan pelayanan dan dorongan kepada masyarakat. Kegiatan imunisasi merupakan kegiatan rutinitas, yaitu program yang dijalankan secara terus menerus, oleh karena itu sekalipun pengetahuan ibu kurang baik tentang imunisasi tidak akan mempengaruhi pelaksanaan imunisasi pada anak (Sastroasmoro, 2007).

\section{KESIMPULAN}

Hasil penelitian ini tidak ada hubungan yang signifikan antara tingkat pengetahuan ibu tentang imunisasi dengan kelengkapan imunisasi dasar anak dibuktikan dengan hasil perhitungan pValue: $0.410>0.05$ dan $X^{2}$ hitung $1.783<X^{2}$ tabel $(1.783<5.991)$. 


\section{DAFTAR PUSTAKA}

Anonim. (2007). Imunisasi.

http://www.pusat-informasi-

penyakit-infeksi.com, diperoleh tanggal 30 Januari 2017

Avid Rudha Yustifa. (2008). Hubungan

Tingkat Pengetahuan Ibu Tentang Imunisasi Polio Dengan Perilaku Pasca Pemberian Imunisasi Polio Pada Bayi di RB An - Nissa, Surakarta: D3 Kebidanan STIKES Aisyiyah

Azwar, S. (2008). Reliabilitas dan Validitas. Cetakan kedelapan. Pustaka Pelajar: Jakarta

Hidayat, A. (2007). Metode Penelitian Kebidanan Teknik Analisis Data. Salemba Medika: Jakarta

Notoatmodjo, S. (2007). Metodologi Penelitian Kesehatan. Cetakan ketiga. PT. Rineka Cipta: Jakarta

Ranuh, I.G.N. (2008). Pedoman Imunisasi di Indonesia. Cetakan ketiga. Satgas Imunisasi: Jakarta

Sastroasmoro, S. (2007). Membina Tumbuh-Kembang Bayi dan Balita. IDAI: Jakarta

Sugiyono. (2007). Statistika untuk Penelitian. Cetakan Kesebelas. Alfabeta: Bandung 